\title{
Knowledge and attitudes of Brazilian dentists regarding dental treatment of children
}

\author{
Marília Leão Goettems ${ }^{a}$, Marina Sousa Azevedo ${ }^{a}$, Dayane Rubin ${ }^{b}$, Núbia Rubin Prietto ${ }^{b}$, Laís Anschau Paulic, \\ Flávio Fernando Demarco ${ }^{d}$
}

\begin{abstract}
OBJECTIVE: This survey assessed the attitudes of dentists regarding dental treatment of children, the barriers reported, and knowledge about the recommended age for a child's first dental visit. METHODS: A self-applied questionnaire was sent to all dentists in Pelotas/Brazil and 187 (67.8\%) were returned. The chi-square test was used to analyze categorical or nominal variables; the chisquare test for linear trend was used for the ordinal variables and Fisher's exact test was used when the cell frequencies were small. The level of significance was set at $\alpha=0.05$.

RESULTS: The majority of the dentists provide dental treatment for children (123; 71.9\%). Regarding the barriers to treatment of children, behavior (55.9\%) and interest of parents (48.2\%) were the most cited. Only 65.9\% reported that children should see a dentist no later than 12 months of age. Knowledge about the recommended age was higher among pediatric dentists $(p=0.03)$ and lower among dentists in private practice $(p=0.002)$ and with more years of practice $(p=0.02)$.

CONCLUSIONS: Although most of the dentists treat children, barriers have been pointed out. Many of the dentists are not aware of the recommended age for the first dental visit. Given the benefits of early treatment, this attitude should be stimulated among dental professionals.
\end{abstract}

Keywords: pediatric dentistry; dentists; child; dentistry.

\section{Conhecimento e atitudes dos dentistas brasileiros em relação ao tratamento odontológico de crianças}

\section{RESUMO}

OBJETIVO: Esta pesquisa avaliou as atitudes dos dentistas em relação ao tratamento odontológico de crianças, as barreiras relatadas e o conhecimento sobre a idade recomendada para a primeira consulta odontológica da criança.

MÉTODOS: Um questionário auto-aplicado foi enviado a todos os dentistas em Pelotas/Brasil e 187 (67,8\%) foram devolvidos. O Teste Qui-quadrado foi utilizado para analisar variáveis categóricas ou nominais; Qui-quadrado para tendência linear foi usado para as variáveis ordinais e o Teste Exato de Fisher foi usado quando as frequências celulares eram pequenas. O nível de significância foi estabelecido em $\alpha=0,05$.

RESULTADOS: A maioria dos dentistas oferece tratamento odontológico para crianças $(71,9 \%)$. Quanto às barreiras ao tratamento de crianças, o comportamento $(55,9 \%)$ e o interesse dos pais $(48,2 \%)$ foram os mais citados. Apenas $65,9 \%$ relataram que as crianças devem consultar um dentista até os 12 meses de idade. 0 conhecimento sobre a idade recomendada foi maior entre odontopediatras $(p=0,03)$ e menor entre dentistas em prática privada $(p=0,002)$ e com mais anos de prática $(p=0,02)$.

CONCLUSÃO: Embora a maioria dos dentistas tratem crianças, as barreiras foram apontadas. Muitos dentistas não estão conscientes da idade recomendada para a primeira visita odontológica. Dado os benefícios do tratamento precoce, essa atitude deve ser estimulada entre os dentistas.

Palavras-chave: odontopediatria; dentistas; crianças; odontologia. adjunct Professor, Post-Graduate Program in Dentistry, School of Dentistry, Federal University of Pelotas, Pelotas, Brazil

b DDS, Federal University of Pelotas, Pelotas, RS Brazil

${ }^{c}$ Post-Graduate Student, Dental School, Federal University of Pelotas, Pelotas, RS, Brazil

${ }^{d}$ Full Professor, Post-Graduate Program in Dentistry, School of Dentistry, Federal University of Pelotas, Pelotas, Brazil

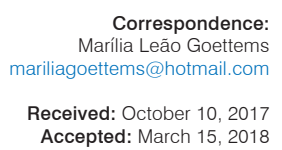

Conflict of Interests: The authors state that there are no financial and personal conflicts of interest that could have inappropriately influenced their work.

Copyright: ( 2017 Goettems et al licensee EDIPUCRS.

This work is licensed under a Creative Commons Attribution 4.0 International License. 


\section{INTRODUCTION}

It is recognized that children's oral health has improved over time, with a decrease in the occurrence of dental caries. However, a considerable number of children still are affected by this disease [1]. Other conditions such as dental trauma and malocclusion are also common in childhood and may require treatment [2].

Therefore, it is recommended that the first visit to a dentist should occur within the first year of a child's life [3]. This early visit gives the dentist a chance to improve the child's oral hygiene, correct improper dietary and eating habits, improve parents' knowledge of the role of nonnutritive sucking for the development of malocclusions, and educate about the risks of traumatic injuries [4]. In addition, the dentist may check for signs of early decay.

However, in Brazil, only a small percentage of the children visit the dentist, and usually they do not do it at the recommended age [5-7]. The same has been observed in other countries [8]. Also, restorative treatment in primary teeth is suboptimal [9]. A recent oral survey showed that only $1.7 \%$ of the children with or more decayed, missing or filled teeth had had restored or extracted teeth [10].

Many reasons have been cited as barriers to children's dental visits. Social class, maternal schooling, and attendance pattern and health system availability are frequently assessed $[6,11]$. Nevertheless, studies have concentrated mostly on the children and their parents.

It is possible that professional knowledge and attitudes may also limit the use of dental services by children $[12,13]$. Thus, given the benefits of early dental visits, it is important to know whether dentists are aware of this recommendation. Also, it is important to know their opinion about the reasons that could represent barriers to providing dental care for children, as many professionals may not feel confident enough or adequately trained to treat very young children [14].

The aim of this study was to assess the attitudes of dentists regarding the dental treatment of children in a southern Brazilian city, the barriers reported, and their knowledge about the recommended age for a child's first dental visit.

\section{METHODS}

This cross-sectional study was approved by the Human Research Ethics Committee of the Federal University of Pelotas (116/2009). Pelotas had nearly 327,000 inhabitants in 2009 [15]. A list of all dentists active in 2009 in the city was obtained from the Local Board of Dentistry. Those whose data were complete (address and telephone number) were eligible to be included ( $\mathrm{n}=276$ ).

Dental students handed out the questionnaires at the addressed listed between March and July, 2010. All practitioners received an explanation of the study and were given the opportunity to ask questions. If the professional agreed to participate in the study, the survey was completed and the student would return after a week to collect the selfapplied questionnaire and the signed informed consent form.

\section{Questionnaire}

A previously tested self-administered questionnaire consisting of 48 closed-ended items with response options organized vertically was used for the data collection. In the present study, variables regarding demographic characteristics (sex, age), professional data (workplace, number of years of professional activity, and specialization), recommended age for the first dental visit, attitudes toward the treatment of children in primary dentition (if providing dental treatment for children or referring to other colleagues), and the barriers encountered were used. The recommended age for the first visit was collected in years and categorized as follows: by 1 year of age or $>$ than 1 year of age. The workplace was considered public, private, both, or dental school. Years of dental practice was categorized into four groups: less than 10 years; 10 to 20 years; 21 to 30 years; and 30 years or more. The type of license was classified as general practitioner, pediatric dentistry, or other specialty.

The questionnaire responses were tabulated twice to detect errors. The percent frequency distributions for the responses to each item were computed. The chi-square test was used to analyze categorical or nominal variables; the chi-square test for linear trend was used for the ordinal variables and Fisher's exact test was used when the cell frequencies were small. The data were analyzed using Stata 12.0 (Stata Corporation, College Station, TX, USA). The level of significance was set at $\alpha=0.05$.

\section{RESULTS}

Of the 276 surveys delivered, 187 were returned (for response rate of $67.8 \%$ ). Table 1 associates the characteristics of the dentist with the treatment of children. One hundred and twenty-three dentists $(71.9 \%)$ provide dental treatment for children. No differences were observed between the sexes, the years of clinical practice and the types of licenses. Dentists who work in the public service tend to provide care for children in a higher than those who only work in private practice or work at University.

Table 2 shows the barriers highlighted by dentists regarding the dental treatment of children. More than one option was allowed, and the most frequently cited one was child behavior, followed by a lack of parental interest in taking the child to the dentist.

The practitioners who treat children in their offices were asked about the procedures they perform and those they refer to colleagues. Most dentists reported referring endodontic and preventive orthodontic procedures to colleagues, whereas preventive procedures and extractions were performed by most dentists (Table 3).

When asked about the recommend age for a child's first dental visit, $65.9 \%$ reported that children should see a dentist at no later than 12 months of age. The responses were compared according to the dentists' characteristics. It was found that all pediatric dentists were aware of this recommendation $(\mathrm{p}=0.03)$. The difference was also significant according to practice location and years of practice (Table 4). 
Table 1. Description of the sample included and characteristics associated with providing care for children in Pelotas, Brazil ( $n=187$ ).

\begin{tabular}{|c|c|c|c|c|}
\hline \multirow{2}{*}{ Variables } & \multicolumn{4}{|c|}{ Provide care for children } \\
\hline & n (\%) & Yes n (\%) & No n (\%) & P-value \\
\hline $\begin{array}{l}\text { Sex } \\
\text { Male } \\
\text { Female }\end{array}$ & $\begin{array}{l}80(46.8) \\
91(53.2)\end{array}$ & $\begin{array}{l}52(65.0) \\
71(78.0)\end{array}$ & $\begin{array}{l}28(35.0) \\
20(22.0)\end{array}$ & 0.059 \\
\hline $\begin{array}{l}\text { Years of dental practice } \\
\text { Up to } 10 \\
11-20 \\
21-30 \\
\text { More than } 30\end{array}$ & $\begin{array}{l}79(46.7) \\
37(21.9) \\
26(15.4) \\
27(16.0)\end{array}$ & $\begin{array}{l}59(74.7) \\
27(73.0) \\
19(73.1) \\
17(63.0)\end{array}$ & $\begin{array}{c}20(25.3) \\
10(27.0) \\
7(26.9) \\
10(37.0)\end{array}$ & 0.703 \\
\hline $\begin{array}{l}\text { Type of license } \\
\text { General practitioner } \\
\text { Specialist }\end{array}$ & $\begin{array}{c}66(36.3) \\
116(63.7)\end{array}$ & $\begin{array}{l}52(81.2) \\
69(67.6)\end{array}$ & $\begin{array}{l}12(18.8) \\
33(32.4)\end{array}$ & 0.055 \\
\hline $\begin{array}{l}\text { Practice location } \\
\text { Private } \\
\text { Public } \\
\text { Both (private/public) } \\
\text { Dental school }\end{array}$ & $\begin{array}{c}112(66.7) \\
17(10.1) \\
21(12.5) \\
18(10.7)\end{array}$ & $\begin{array}{c}75(67.0) \\
15(88.2) \\
21(100.0) \\
11(61.1)\end{array}$ & $\begin{array}{r}37(33.0) \\
2(11.8) \\
0(-) \\
7(38.9)\end{array}$ & 0.005 \\
\hline
\end{tabular}

Table 2. Barriers perceived by dentists regarding dental treatment of children in Pelotas/Brazil $(n=170)$

\begin{tabular}{lc}
\hline Barriers & $\mathbf{n}(\%)$ \\
\hline Children's behavior & $95(55.8)$ \\
Children's tendency to cry & $19(11.2)$ \\
Lack of parental interest & $82(48.2)$ \\
Low level of reimbursment & $25(14.7)$ \\
Lack of auxiliar staff & $25(14.7)$ \\
Insufficient knowledge or ability & $27(16.0)$ \\
\hline
\end{tabular}

Table 3. Dental procedures performed in children by dentists in Pelotas, Brazil $(n=123)$.

\begin{tabular}{lcc}
\hline Procedures & $\begin{array}{c}\text { Provide } \\
\mathbf{n}(\%)\end{array}$ & $\begin{array}{c}\text { Refer to collegues } \\
\mathbf{n}(\%)\end{array}$ \\
\hline Preventive procedures & $105(90.5)$ & $11(9.5)$ \\
Restorative dentistry & $104(88.9)$ & $13(11.1)$ \\
Preventive orthodontics & $33(28.2)$ & $84(71.8)$ \\
Endodontic procedures & $44(38.6)$ & $70(61.4)$ \\
Radiographic procedures & $81(59.6)$ & $55(40.4)$ \\
Extraction & $107(90.7)$ & $11(9.3)$ \\
Emergency & $101(85.6)$ & $17(14.4)$ \\
\hline
\end{tabular}

Table 4. Dentist characteristics associated with knowledge of the recommendation for a first visit to a dentist by 1 year of age.

\begin{tabular}{|c|c|c|c|}
\hline \multirow[b]{2}{*}{ Variables } & \multicolumn{2}{|c|}{ Age of first visit (years) } & \multirow[b]{2}{*}{$\mathrm{p}$} \\
\hline & $\begin{array}{c}\text { By } 1 \text { year } \\
\text { n (\%) }\end{array}$ & $\begin{array}{c}>1 \text { year } \\
\mathrm{n}(\%)\end{array}$ & \\
\hline $\begin{array}{l}\text { Sex } \\
\quad \text { Male } \\
\text { Female }\end{array}$ & $\begin{array}{l}49(59.0) \\
63(72.4)\end{array}$ & $\begin{array}{l}34(41.0) \\
24(27.6)\end{array}$ & $0.06^{\ddagger}$ \\
\hline $\begin{array}{l}\text { Years of practice } \\
\text { Up to } 10 \\
11-20 \\
21-30 \\
\text { More than } 30\end{array}$ & $\begin{array}{r}54(68.4) \\
30(73.2) \\
20(80.0) \\
7(30.4)\end{array}$ & $\begin{array}{r}25(31.6) \\
11(26.8) \\
5(20.0) \\
16(69.6)\end{array}$ & $0.02^{*}$ \\
\hline $\begin{array}{l}\text { Practice location } \\
\text { Private } \\
\text { Public } \\
\text { Both } \\
\text { Dental School }\end{array}$ & $\begin{array}{l}59 \text { (54.6) } \\
14(82.3) \\
17(85.0) \\
18(85.7)\end{array}$ & $\begin{array}{r}49(45.4) \\
3(17.7) \\
3(15.0) \\
3(14.3)\end{array}$ & 0.002 \\
\hline $\begin{array}{l}\text { Type of license } \\
\text { Pediatric specialist } \\
\text { General practitioner/Other speciality }\end{array}$ & $\begin{array}{c}8(100) \\
100(63.7)\end{array}$ & $\begin{array}{c}0(-) \\
57(36.3)\end{array}$ & $0.03^{\dagger}$ \\
\hline $\begin{array}{l}\text { Provide treatment for children } \\
\text { Yes } \\
\text { No }\end{array}$ & $\begin{array}{l}79(67.5) \\
27(64.3)\end{array}$ & $\begin{array}{l}38(32.5) \\
15(35.7)\end{array}$ & $0.70^{\ddagger}$ \\
\hline Total & $112(65.9)$ & $58(34.1)$ & \\
\hline
\end{tabular}

* chi-square test for linear trend; 'Fisher's exact test; ; chi-square test. 


\section{DISCUSSION}

Dental care is the most common unmet treatment need in children. Also, children are a major segment of the population lacking access or utilization of dental care, and very young children, children with special needs, and children from poor families are those who suffer the most [14]. In Brazil, it was found in 1988 that, among children 0-6 years of age, $77 \%$ had never seen a dentist (6). A study performed in 2009 in southern Brazil yielded similar results [16]. Also, in the U.S., the proportion of children with dental visits increased modestly between 1996 and 2004 (from $42 \%$ to $45 \%$ between 1996 and 2004) [17].

The factors associated with dental service utilization have been widely studied, and it has been proven that dental service utilization is determined by a mix of parental, child, and household factors. Socioeconomic characteristics of the family are strongly associated with dental service use [18]. In Brazil, as in other countries, tooth decay has become clustered within the population, and small groups of children still suffer from significant levels of damaged teeth [19]. Greater disease and untreated disease burden are borne by poor and low-income children and racial/ethnic minorities [17]. It was found that rich children present a prevalence of dental service use that is 5 times higher than that of poor children [6]. Thus, the children who are at the highest risk of dental problems are still those who are least likely to receive dental care. Other parental factors can influence children's use of oral health services. Parental oral healthseeking behaviors for themselves may have an important effect on the oral health-seeking behaviors on behalf of their children [20].

Also, studies have reported a number of barriers to dental care access. In Brazil, access to dental services is limited, and there is inequity in access to dental treatment [21]. It was found that about $4 \%$ of those who sought dental care did not get it. The proportion was $8 \%$ among the poorest compared to $1 \%$ among the richest [6]. This can contribute to decreased dental access for children, as parents who do not obtain dental care for themselves are less likely to bring their children in for dental care [20]. Other factors that affect dental care access include a lack of insurance, a lack of knowledge of where to go for treatment, and limited oral health-related knowledge and attitudes. Also, it has been reported that parents attribute their unmet dental care needs to their dentists' lack of knowledge of how to provide care for children [22].

This study focuses on another possible reason that can prevent families from obtaining needed dental care for their children: the dentists' knowledge and attitudes. Splieth et al. [9] revealed that dentists can also be a considerable barrier to restorative treatment in small children, especially without adequate training in dental schools. In the few studies conducted in relation to dentists' attitudes and behavior regarding dental treatment for kids, it was shown that professionals may not have received proper training or do not feel comfortable treating children. In our study, $16 \%$ of the dentists declared that the reason for not seeing a child was insufficient knowledge or ability. The level of training received in dental school can be significantly associated with their attitude toward treating infants [23].

Infants, children, and adolescents, including those with special health care needs, have a right to dental care. According to the American Academy of Pediatric Dentistry (AAPD) [24], it is unethical for a dentist to ignore a disease or condition because of the patient's age, behavior, or disability. Dentists have an ethical obligation to provide therapy for patients with oral disease or refer for treatment patients whose needs are beyond the skills of the practitioner.

Brickhouse et al. [8] found that only $45 \%$ of the general dentists in Virginia, U.S.A., treat children aged up to 36 months. According to our findings, a reasonable number of dentists are seeing children in their practices $(71.9 \%)$. However, encouraging data from the United States showed that 91 percent of general practitioners treated children [14].

Among the dentists who treat children, most of them provide emergency treatment and perform preventive and restorative procedures, but few dentists perform more complex treatment such as orthodontic and endodontic procedures. This is in accordance with Shulman's finding that fewer dentists are willing to perform more complex procedures, such as restorative dentistry with local anesthesia, for younger children [25].

Child behavior and lack of parental interest were the most frequently cited barriers to the dental treatment of pediatric dentists. Similarly, Stijacic et al. [26] performed a study in Canada with general and pediatric dentists and found that child behavior, tendency to cry, and low parental awareness or interest were identified by dentists as barriers to preventing and managing caries. In a study conducted by Wolf, which assessed the reasons that dentists do not see young children, $20 \%$ of the dentists stated that they preferred to refer infants to a pediatric dentist and $15 \%$ reported that parents do not request appointments for young children [12]. However, Splieth et al. [9] assessed the barriers perceived by dentists such as the children, parents, dental practice, and the health system and found that the parents were no barrier.

In this study, only $65.9 \%$ of dentists reported knowing that patients should have their first dental visit by 1 year of age, the age recommended age by the AAPD [3]. However, $71.9 \%$ of the dentists treat children in primary dentition. This is worrisome because it may indicate a serious access-tocare issue for pediatric dental care: if dentists are not aware of the recommendation, it is unlikely that they will advise families to schedule preventive early visits. Brickhouse et al. found that Californian pediatricians and general dentists were not advising patients to see the dentist by 1 year of age and, concurrently, dentists are not treating patients at 1 year of age [8]. In another study, Seale and Casamassimo [14] showed that only slightly more than one-half of the respondents were aware of the AAPD recommendation. It has also been shown that sometimes, although dentists agree with the 1-year guideline, only a small percentage will, in fact, put it into practice [13]. 
It is worth mentioning that knowledge about the AAPD age for the first dental visit recommendation was significantly associated with less than 30 years of practice, practice location, and type of license, while all pediatric specialists were aware of the recommendation. Our results are in agreement with those of Erickson, demonstrating that general and older dentists were less likely to recommend the year-1 dental visit; this is probably due to the fact that this recommendation is relatively recent.

This is one of the few studies that have assessed dentists' knowledge and attitudes about the dental treatment of children in primary dentition. A self-report questionnaire was used to obtain information from dentists. The representative sample and the high response rate achieved allow a valid assessment of dentists' attitudes and perceptions. This method is widely used in cross-sectional study design where all data can be collected at one point in time while avoiding the interference of the interviewer. Also, our study ensured the confidentiality of the questionnaires, which allows more confident answers and may have contributed to the high response rate. Other surveys with a similar methodology have had a lower response rate $[8,9]$. The age of the participants was not asked; rather, the duration of activity (work experience) was asked; as individuals may go to dental school at any time in their lives, the number of years of professional activity may be more important than age.

\section{CONCLUSION}

Despite the fact that barriers were mentioned, most of the dentists provide dental treatment for children. One worrisome fact is that not all dentists are aware of the recommended age for the first dental visit. Given the benefits of early treatment, it is important that this knowledge be emphasized among professionals so they can advise parents to schedule early preventive visits.

\section{REFERENCES}

1. Kassebaum NJ, Bernabe E, Dahiya M, Bhandari B, Murray CJ, Marcenes W. Global burden of untreated caries: a systematic review and metaregression. J Dent Res. 2015 May;94(5):650-8. https://doi. org/10.1177/0022034515573272

2. Bardellini E, Amadori F, Pasini S, Majorana A. Dental Anomalies in Permanent Teeth after Trauma in Primary Dentition. J Clin Pediatr Dent. 2017;41(1):5-9. https://doi.org/10.17796/1053-4628-41.1.5

3. AAPD. Policy on early childhood caries (ECC): classifications consequences, and preventive strategies. Pediatric Dentistry. 2015;37(6):50-2

4. Goncalves JA, Moreira EA, Rauen MS, Rossi A, Borgatto AF. Associations Between Caries Experience, Nutritional Status, Oral Hygiene, and Diet in a Multigenerational Cohort. Pediatr Dent. 2016;38(3):203-11.

5. Kramer PF, Ardenghi TM, Ferreira S, Fischer LA, Cardoso L, Feldens CA. Use of dental services by preschool children in Canela, Rio Grande do Sul State, Brazil. Cad Saude Publica. 2008 Jan;24(1):150-6. https://doi. org/10.1590/S0102-311X2008000100015

6. Barros AJD, Bertoldi AD. Desigualdades na utilização e no acesso a serviços odontológicos: uma avaliação em nível nacional Ciênc. saúde coletiva. 2002;7(4):709-17. https://doi.org/10.1590/S141381232002000400008
7. Goettems ML, Ardenghi TM, Demarco FF, Romano AR, Torriani DD. Children's use of dental services: influence of maternal dental anxiety, attendance pattern, and perception of children's quality of life. Community Dent Oral Epidemiol. 2012 Oct;40(5):451-8. https://doi.org/10.1111/ j.1600-0528.2012.00694.x

8. Brickhouse TH, Unkel JH, Kancitis I, Best AM, Davis RD. Infant oral health care: a survey of general dentists, pediatric dentists, and pediatricians in Virginia. Pediatr Dent. 2008 Mar-Apr;30(2):147-53.

9. Splieth $\mathrm{CH}$, Bunger B, Pine C. Barriers for dental treatment of primary teeth in East and West Germany. Int J Paediatr Dent. 2009 Mar;19(2):84-90. https://doi.org/10.1111/j.1365-263X.2008.00949.x

10. Ministério da Saúde. Projeto SB Brasil 2003. Condições de saúde bucal da população brasileira, 2002-2003: resultados principais. Brasília: Ministério da Saúde; 2004. 52 p.

11. Piovesan C, Antunes JL, Guedes RS, Ardenghi TM. Influence of selfperceived oral health and socioeconomic predictors on the utilization of dental care services by schoolchildren. Braz Oral Res. 2011 Mar-Apr; 25(2):143-9. https://doi.org/10.1590/S1806-83242011005000004

12. Wolfe JD, Weber-Gasparoni K, Kanellis MJ, Qian F. Survey of lowa general dentists regarding the age 1 dental visit. Pediatr Dent. 2006 July-Aug;28(4):325-31

13. Erickson PR, Thomas HF. A survey of the American Academy of Pediatric Dentistry membership: infant oral health care. Pediatr Dent. 1997 Jan-Feb; 19(1):17-21.

14. Seale NS, Casamassimo PS. Access to dental care for children in the United States: a survey of general practitioners. J Am Dent Assoc. 2003 Dec;134(12):1630-40. https://doi.org/10.14219/jada.archive. 2003.0110

15. IBGE. Estimativas de População 2009 [14, august 2009]. Available from http://www.ibge.gov.br/home/estatistica/populacao/estimativa2009/ POP2009_DOU.pdf

16. Goettems ML, Ardenghi TM, Romano AR, Demarco FF, Torriani DD. Influence of maternal dental anxiety on oral health-related quality of life of preschool children. Qual Life Res. 2011 Aug;20(6):951-9. https://doi. org/10.1007/s11136-010-9816-0

17. Edelstein $\mathrm{BL}, \mathrm{Chinn} \mathrm{CH}$. Update on disparities in oral health and access to dental care for America's children. Acad Pediatr. 2009 Nov-Dec;9(6):415-9. https://doi.org/10.1016/j.acap.2009.09.010

18. Engelmann JL, Tomazoni F, Oliveira MD, Ardenghi TM. Association between Dental Caries and Socioeconomic Factors in Schoolchildren--A Multilevel Analysis. Braz Dent J. 2016 Jan-Feb;27(1):72-8. https://doi org/10.1590/0103-6440201600435

19. Jone K, Allen C, Hill A. Tooth decay in five-year-old children in South East England. South East England: Public Health Observatory; 2005.

20. Isong IA, Zuckerman KE, Rao SR, Kuhlthau KA, Winickoff JP, Perrin JM Association between parents' and children's use of oral health services. 2010 Pediatrics. Mar;125(3):502-8

21. Antunes JL, Narvai PC. Dental health policies in Brazil and their impact on health inequalities. Rev Saude Publica. 2010 Apr;44(2):360-5. https:/ doi.org/10.1590/S0034-89102010000200018

22. Flores G, Tomany-Korman SC. Racial and ethnic disparities in medica and dental health, access to care, and use of services in US children Pediatrics. 2008 Feb;121(2):e286-98. https://doi.org/10.1542/peds. 2007-1243

23. Cotton KT, Seale NS, Kanellis MJ, Damiano PC, Bidaut-Russell M McWhorter AG. Are general dentists' practice patterns and attitudes about treating Medicaid-enrolled preschool age children related to dental school training? Pediatr Dent. 2001 Jan-Feb;23(1):51-5

24. AAPD. Policy on the Ethical Responsibilities in the Oral Health Care Management of Infants, Children, Adolescents, and Individuals with Special Health Care Needs. Pediatric Dentistry. 2015;37(6):114-5.

25. Shulman ER, Ngan P, Wearden S. Survey of treatment provided for young children by West Virginia general dentists. Pediatr Dent. 2008 Jul-Aug;30(4):352-7

26. Stijacic T, Schroth RJ, Lawrence HP. Are Manitoba dentists aware of the recommendation for a first visit to the dentist by age 1 year? J Can Dent Assoc. 2008 Dec;74(10):903 